\title{
Digital campaigning as a policy of democracy promotion: Applying deliberative theories of democracy to political parties
}

\author{
Eva Odzuck (iD · Sophie Günther
}

Accepted: 7 December 2021 / Published online: 23 December 2021

(C) The Author(s) 2021

\begin{abstract}
Today's election campaigns are heavily data-driven. Despite the numerous skeptical voices questioning the compatibility of specific campaigning practices with fundamental principles of liberal democracies, there has to date been little comprehensive work in this area from the perspective of normative democratic theory. Our article addresses this gap by drawing on recent research on the normative theory of political parties in the field of deliberative democratic theory. The deliberative theories of democracy proposed by Habermas and Rawls contain structural elements of a normative theory of the political party: the special status of political parties as mediators between background culture and the political forum, between the political system and the public sphere, and between the individual and the state, confers on them a central position as actors in in the public use of reason and deliberation.

We argue in this article for a view of digital campaigning as a policy of democracy promotion and for the proposition that, alongside other actors, political parties have a special responsibility in this regard. We point to the implications for the evaluation and design of digital political microtargeting that arise from the application of deliberative principles to political parties and consider the need they reveal for the ongoing development of detailed, nuanced normative theories of democracy.
\end{abstract}

Keywords Deliberative democratic theory - Political parties - Rawls - Habermas · Digital campaigning $\cdot$ Microtargeting

Dr. Eva Odzuck $(\bowtie) \cdot$ Sophie Günther

Chair of Political Philosophy, Political Theory, and History of Political Ideas,

Friedrich-Alexander-University Erlangen-Nuremberg, Kochstr. 4/21, 91054 Erlangen, Germany

E-Mail: eva.odzuck@fau.de 


\section{Digitaler Wahlkampf als Politik der Demokratie - die Anwendung deliberativer Demokratietheorien auf politische Parteien}

Zusammenfassung Heutige Wahlkämpfe sind stark datengesteuert. Trotz der zahlreichen skeptischen Stimmen, die die Vereinbarkeit spezifischer Wahlkampfpraktiken mit den Grundprinzipien liberaler Demokratien in Frage stellen, gibt es bisher nur wenige umfassende Arbeiten aus der Perspektive der normativen Demokratietheorie. Unser Artikel adressiert diese Lücke, indem er sich auf neuere Forschungen zur normativen Theorie politischer Parteien aus dem Bereich der deliberativen Demokratietheorie stützt. Die von Habermas und Rawls vorgeschlagenen deliberativen Demokratietheorien enthalten Strukturelemente einer normativen Theorie der politischen Partei: Der besondere Status politischer Parteien als Vermittler zwischen Hintergrundkultur und politischem Forum, zwischen politischem System und Öffentlichkeit sowie zwischen Individuum und Staat verleiht ihnen eine zentrale Stellung als Akteure des öffentlichen Vernunftgebrauchs. Wir plädieren in diesem Artikel dafür, Digital Campaigning auch als Politik der Demokratieförderung zu verstehen und den politischen Parteien hierfür, neben anderen Akteuren, eine besondere Verantwortung zuzuweisen. Wir diskutieren Implikationen, die sich aus der Anwendung deliberativer Prinzipien auf politische Parteien für die Evaluierung und Gestaltung von digitalem politischem Microtargeting ergeben und betrachten die Notwendigkeit, die sich daraus für die Weiterentwicklung detaillierter, nuancierter normativer Theorien der Demokratie ergibt.

Schlüsselwörter Deliberative Demokratietheorie · Politische Parteien · Rawls · Habermas · Digitale Wahlkampagnen · Digitales Micro-Targeting

\section{The practice of digital political microtargeting in election campaigns and the gap in normative theories of democracy}

If you are a 38-year-old white man, living with a partner and children in a "swing state" in the U.S., and if you have views on the subjects of religion, sexual orientation, and guns, you are likely to find tailored messages in your inbox or newsfeed that seek to convince you that a certain party will take care of your values and interests. If you are a 64-year-old Black woman with other values and interests, living in a state that traditionally votes the same way at each election, you are likely to receive different political advertisements from the same parties, and there will be fewer of them, as you do not live in a swing state. This practice of "digital political microtargeting" in the political sphere, and the immense centrality of data to modern election campaigns, stem from the digital contexts in which many of the actions and interactions undertaken by contemporary citizens take place. In navigating through the digital world and in using online services, citizens leave digital traces which enable organizations such as political parties to generate profiles of voters on the basis of these data. In election campaigns, profiling can serve to divide the electorate into specific groups and target them accordingly with bespoke messaging. Drawing on a study by Kruschinki and Haller (2017, p. 3), we define digital 
political microtargeting as "a strategic process, which is geared towards addressing pursuable or mobilisable voters with tailor-made massages while ignoring others". It thus combines data collection and aggregation, voter segmentation and profiling, and the creation and testing of personalized messaging (Harker 2020, p. $153 \mathrm{f}$.). Predictive profiling aims at predicting political views and party allegiances, the probability that a person will use their vote, and the issues that will resonate with that individual. Psychographic profiling uses personality traits inferred from online behavior or personality tests to craft persuasive messages (Harker 2020, p. 154). Political parties in the U.S. - and indeed in Europe ${ }^{1}$ — use these techniques to identify voters their messaging may be likely to win over and to match this messaging to these voters' specific interests and vulnerabilities (Zuiderveen Borgesius et al. 2018, p. 82). Advantages of these techniques for political parties include access to a way of addressing voters across the entire political spectrum, rather than being restricted to targeting a campaign toward the average voter. Further, direct communication of political messaging reduces the risk that the party will alienate other voters who are not receptive to the message (see Papakyriakopoulos et al. 2018, p. 2).

Digital political microtargeting can be manipulative, but is not necessarily so. A more general problem of political advertising in election campaigns is what we will call dual information asymmetry. In general, platforms (and political parties who buy platform services) have more information about the individual voter than vice versa and, more importantly, they use this information to build digital choice environments. The selection and personalization of messaging in line with a previous division of the electorate into different target groups additionally generate asymmetries of information within the electorate and among voters, because some people receive some advertisements, while others get different ones or none at all.

Although the phenomenon of digital microtargeting in the political arena is widespread, and some actors in the discourse have raised concerns around potential negative effects of the practice on democracy (cf. Zuiderveen Borgesius et al. 2018), we remain without comprehensive studies of digital microtargeting from the perspective of normative theories of democracy (see Odzuck 2020). Recent studies often focus on the regulation of platforms or the creation of new legislative frameworks for political advertising (cf. Harker 2020; Dobber et al. 2019a; Zuiderveen Borgesius et al. 2018). The rare approaches to the phenomenon from a normative point of view tend to center platforms, leaving political parties out or restricting themselves to discussing them in passing. ${ }^{2}$ One reason for this gap in normative theories of democracy is their emergence, in the main, in the period prior to the rise of digital technologies; they therefore require elaboration for and application to our digital age. A second reason relates to a "blind spot" in such normative theories with respect to political parties and election campaigns: While political science

\footnotetext{
1 While the electoral system and the legislation on the collection of data in force in a country do, of course, influence the practice, it would be dangerous to dismiss the phenomenon as a problem of the U.S. alone, as Bennett (2016, p. 274) convincingly argues. Regarding the phenomenon in Germany, see Papakyriakopoulos et al. 2018.

2 See Baldwin-Philippi et al. (2020), who discuss ethical principles for digital campaigning, but focus on online platforms rather than on political parties. The same is true for the 2020 report of the Kofi Annan Commission on Elections and Democracy in the Digital Age (2020).
} 
(Muirhead and Rosenblum 2006, p. 100) and realist theories of democracy (Downs 1957; Achen and Bartels 2016) both afford a central position to political parties, normative theories neglected them for a long period of time (Lipsitz 2004, p. 185). Until recently, the famous assertion by Schattschneider (1942, p. 16) that political parties are "the orphans of political philosophy" was highly apposite to twenty-firstcentury normative theories of democracy ${ }^{3}$, holding particularly true of deliberative theories, which were known for their neglect of and generally skeptical stance with respect to political parties (cf. Johnson 2006, p. 48). Happily, the last two decades have seen attempts to address this lacuna in normative theories of democracy, with several studies adding precision to existing theories with regard to political parties' role. Notwithstanding substantial differences within this newer body of research, ${ }^{4}$ a frequently occurring stance is the conviction that parties do in fact fulfill necessary and highly important functions for deliberative democracies. ${ }^{5}$

Our article draws on these more recent studies. Because political parties are among the key actors in election campaigns as they take place in modern democracies, it makes sense to develop an outline for an ethos of digital campaigning through the lens of a normative theory of the political party as a deliberative actor. Such a focal emphasis need not deny or neglect the multiplicity of actors involved in the evolution of digital campaigning, which, if we consider the existence of an entire industry around online platforms and the size of the associated ecosystem, amounts to a "shifting and hidden network of actors between party and voter."' Political parties certainly do not bear the primary responsibility for this broad-ranging and complex problem, and we cannot expect to attain a simple solution by targeting them and them alone. Exploring their role, however, would appear a promising approach in light of a view of them as complex actors whose unique position within this new data-driven communication industry confers on them particular obligations. It is additionally the case that increased public awareness of problematic campaigning practices may provide incentives to political parties to obey some of the normative principles we will now proceed to outline. We will argue that the status of political parties as complex deliberative actors makes it incumbent upon them, when they engage in digital campaigning, to respect fundamental tenets of public deliberation. Because political parties form a bridge between background culture and public political culture (Rawls), connect the political system (formal political sphere) to the general public or civil society (informal political sphere, Habermas), and aim to represent both the state and the individual citizen, they have, in the act of campaigning, a special civic duty (Rawls). In other words, political parties' mediating function, their dual role in representation, and their influence on public deliberation confer on them the obligation to conceive of digital campaigning not only as a tool for mobilizing voters and for winning votes, but also as part of a broader policy of

\footnotetext{
3 For an overview of recent political theories relating to political parties, see Muirhead/Rosenblum (2020) and Bonotti (2017, p. 1 f.).

4 See, for example, the discussions between Muirhead (2019) and White/Ypi (2019).

5 The relative importance of each of these functions remains a matter of dispute; see Muirhead/Rosenblum (2020, p. 102).

6 This is a quotation from one of the reviews of our article.
} 
promoting democracy, from which it follows that they should develop and follow an ethos for and in their digital campaigning. ${ }^{7}$

In making this case, we will turn to the deliberative theories of Habermas (section 2.1 of the article) and Rawls (2.2). In each case, we will first outline principles of deliberation and public reason, before discussing the extent to which we may, or indeed need to, apply these principles to campaigning political parties, drawing on recent studies on political parties as actors of public deliberation in normative theories of democracy. We then apply these principles of public deliberation to campaigning political parties, pointing to the conclusions we may (and those we may not yet) draw for the evaluation and design of digital political microtargeting. Concluding (3), we will summarize our considerations and discuss the necessity of evolving political theories that predate the digital for the settings and media of our current age.

\section{Digital political microtargeting as a policy of democracy promotion}

\subsection{Habermas's principles of discourse as a normative foundation for digital campaigning by political parties}

The nucleus of all deliberative theories of democracy is deliberation, consisting in the weighing of arguments in pursuit of understanding (Schmidt 2010, p. 237); from this issues the primacy of public deliberation over collective majority decision-making. This understanding- and consensus-centered conception of democracy has received scholarly and sociopolitical attention in recent decades (Bohman 1996; Schaal and Heidenreich 2009, p. 23), leading to a "deliberative turn" (Schlosberg and Dryzek 2002, p. 332; Pettit 2004, p. 55 f.). Jürgen Habermas's contribution to scholarship is considered one of the most influential in the development of deliberative literature, as no other political theory has shaped the discourse as significantly (cf. Greve 2009; Hudget 2007; Landwehr 2012; Schmidt 2010). As a "frequent point of reference" (Blake 1995, p. 355) in philosophical scholarship, his work will serve as a foundation for the development of an outline for an ethos of digital campaigning in this article.

\subsubsection{Principles of discourse and rules of deliberation}

Though we are admittedly unable to equitably cover the extensive literature on deliberative democratic theory in its entirety, it seems imperative to commence by setting out some fundamental theoretical aspects of the issue at hand. Deliberations

\footnotetext{
7 Parties face the requirement to fulfill numerous different functions that on occasion require a diversity of means; they include mobilizing the electorate, recruiting leaders, formulating policy recommendations, and structuring political competitive arena. From the outset, therefore, our chosen focus on deliberative theories of democracy is a normative choice in favor of one type of normative theory of democracy, which appears to prioritize some deliberative functions of political parties over others. However, as we do not seek to produce a general theory of political parties, but rather elaborate on their role in deliberative theories of democracy and make a case for their deliberative obligations as complex and special actors, we regard this choice and the consequent focus one type of function of political parties as justified, indeed necessary.
} 
are argumentative disputes structured by clearly defined rules of discourse, aiming at cooperatively verifying the truth of hypotheses and reaching the best possible state of agreement (cf. Habermas 1991; Brunkhorst et al. 2009; Greve 2009). Deliberation in general is characterized by a communication-oriented, interactive, and thus reciprocally inclusive exchange of arguments and counterarguments (Habermas 1996, p. 181, 235). In this context, the deliberative school acknowledges the paradigmatic predominance of the maxim of the "best argument" and the associated willingness on the part of actors in the discourse to give up their own stance in favor of the superior one (cf. Manin 1987, p. 367; Schaal and Heidenreich 2009, p. 23). This theory regards deliberation as a crucial task for society as a whole, by no means located exclusively on an institutional level, i.e. in parliamentary or party circles, but rather an inclusive ideal concerned with the fundamental equality and openness of deliberation, its specific topics and its participants.

Habermas's considerations, informed by his discourse theory, give rise to six key conditions or "postulates" that are concerned with equality as well as transparency. In particular, Between Facts and Norms (1996) contains largely unambiguous definitional criteria, which provide crucial insight into the essence of deliberation (Habermas 1996, p. $305 \mathrm{f}$.). It is possible to summarize and formalize the core premises relating to political deliberation as follows (cf. Habermas 1984, p. 119f., $177 \mathrm{ff}$., 1996, p. 305 f., 2004, p. 119):

- $\mathrm{P}_{1}$ : All speakers have equal rights. They are all free to initiate discourses and to influence, frame, and structure them by means of interaction.

- $\mathrm{P}_{2}$ : There must be de facto equal distribution of opportunities for communication, i.e. opportunities to contribute assertions, interests, rebuttals, etc. to the discourse, among all participants.

- $\mathrm{P}_{3}$ : Each and every participant in the discourse must be equally permitted to introduce "representative speech acts"- that is to say, statements reflecting their own emotions and points of view-into the discourse.

- $\mathrm{P}_{4}$ : The argumentative process of deliberation must reflect a dialogical structure (reciprocity).

- $\mathrm{P}_{5}$ : Deliberation shall be free from internal and external constraints. The structure of communication must neither favor nor exclude specific participants. External and internal influences stemming from power relations must neither arise in deliberation nor be brought into the deliberative speech situation from the practical world.

- $\mathrm{P}_{6}$ : The ideal process of deliberation is subject to the precept of the "unforced force of the better argument", which guides the actions and decisions that take place in this process. It is solely the best argument that settles the consensual outcome of the deliberative process.

Nevertheless, as is common in normative theory, these postulates framing the Habermasian "ideal speech situation" describe an "ought" state which in reality is unattainable and thus far unattained. We may by no means read it as a feasible

\footnotetext{
8 On Habermas's conception of this term, its initial use in his understanding of the validity of propositions, and his reference to it as a "misleading expression" (871) in hindsight, see Habermas (2018, p. 871).
} 
archetype; instead, it serves as a critical benchmark for the empirical investigation of speech situations (Görtz 2015, p. $149 \mathrm{f}$; Rasmussen 2019, p. 183), a status it is important to keep in mind when referring to this concept for analysis. ${ }^{9}$

\subsubsection{Political parties and their vital role as deliberative agents}

The significance to democratic legitimacy and stability that Habermas's thinking assigns to political parties may initially fail to reveal itself if we first recall his much-referenced critique of parliamentarism (cf. Becker 2003; Linden 2014) and its striking "discontentment with political parties" (Tinnevelt 2020, p. 109). This notwithstanding, his discourse theory and his understanding of deliberative processes allow for a different, far more positive view: In his theory, political parties play a key role and thus enable us to regard them as central institutions of democracy. In a manner similar to Sartori (1976, p. ix), Habermas recognizes political parties' performance of a mediating function. Political parties are more than mere structural elements (cf. Lechner 2019, p. 87 f.). They are crucial instruments of understandingbased decision-making. In their communicative function, they represent citizens' divergent social interests, contributing substantially in this way to the aggregation and articulation of political interests. Alongside this, the arguments they put forward for these divergent points of view significantly advance the constitution and reproduction of the public sphere as a network for the communication of content and opinions (Habermas 1996; cf. Siri 2011). We note in this context that Between Facts and Norms (1996), the work by Habermas to which we primarily refer here, did not take a position critical of representative forms of democracy. Following Gaus's convincing argument (cf. Gaus 2013, p. 269 ff.), we can read this work as conceiving of deliberative democracy as a modern expression of a representative institutional order connecting the concepts of democracy and representation.

The high significance Habermas ascribes to the public sphere and the discourses conducted therein sheds new light on political parties' essential importance to deliberative democracy. By constantly criticizing, discussing, but also publicly articulating "opinions which have been formed in the communication exchange of issuerelevant positions, information and reasons" (Habermas 2012, p. 135), political parties enrich the public sphere with new discourses. In this way, they act to mobilize the citizenry, serving as initiators of new deliberations, cues for the formation of public opinion, and consequently as decisive voices in the deliberative will and the deliberative decision-making process at societal and political level (Habermas 2018, p. $878 \mathrm{f}$.). Political parties can take the initiative to articulate apparently weaker positions or the interests of less influential groups of the citizenry in equal measure to positions or interests stemming from ostensibly more powerful sources (cf. $\mathrm{P}_{1}, \mathrm{P}_{2}$, $\mathrm{P}_{3}$ ). In deliberation, political parties therefore speak for others and can help ensure all interests and positions receive an equal hearing in the discursive process (cf. $\left.\mathrm{P}_{1}\right)$.

\footnotetext{
9 Moreover, it may be noted that the concept of an ideal speech situation originates from Habermas's discourse ethics, in which he provides a nuanced consideration of necessary preconditions for and constraints on communication.
} 
While Tinnevelt (2020) wonders how to "reconcile [Habermas's] [...] spatial logic of his two-track model of deliberative politics [...] with the non-spatial status and function of political parties" (115), we would argue that political parties' forging of a link between the macro- (civil society) and the micro-deliberative setting (the institutionalized public sphere, such as parliament) justifies a view of political parties as legitimate actors both participating in and mediating between these two "specialized deliberative arena[s]" (Habermas 2006, p. 415). Being both legitimate "vehicles for and [...] sites of political deliberation and participation" (Tinnevelt 2020, p. 110; emphasis by author), political parties are equally committed to the applicable discursive rules of deliberation and to high standards of public communication. To this end, a political party must "get involved in the deliberative style and internal logic of political discourses" (Habermas 1996, p. 273), which includes the equality of all speakers among themselves $\left(\mathrm{P}_{1}, \mathrm{P}_{2}, \mathrm{P}_{3}\right)$, the preservation of the reciprocal or argumentative-dialogical form of deliberation $\left(\mathrm{P}_{4}\right)$, mutual respect, the exclusion of external and internal influences stemming from power relations $\left(\mathrm{P}_{5}\right)$, and a broad openness for the topics or problems to be deliberated $\left(\mathrm{P}_{5}\right)$. The overall range of political parties' function therefore extends far beyond the conventional parliamentary-governmental and electoral tasks which research in this area generally tends to emphasize (see, for example, Jun 2013, p. 120). In view of the importance of political parties to the emergence and quality of deliberation, we are called to add a deliberative dimension to the spectrum of their functions. In the light of these considerations, and following the assertion by White and Ypi (2019, p. 106) that political "parties differ from factions precisely in their ability to articulate principles and aims that meet deliberative criteria for reason-giving, that is, general and reciprocal justifiability", it appears imperative to apply deliberative principles to political parties' public (and non-public) actions, specifically-in our context- to their practices of digital campaigning. ${ }^{10}$

\subsubsection{Deliberative principles for political parties engaging in digital campaigning}

Political parties' status as deliberative actors within the democratic process of formation of public opinion and will, and their consequent significance to the emergence and quality of deliberation (in its ideal state), confers on them, in our view, a responsibility to adhere to certain norms in political campaigning. In this context, we regard Habermas's rules of discourse and communication as an initial guide to sketching

\footnotetext{
10 We take a critical view of the argument put forward by Gardner (2009) that campaigns need not be heavy on deliberative content due to the existence of other opportunities for meaningful deliberation in other settings. In our view, political parties' role-model function means they transmit norms of public communication and thus contribute to the possibility and quality of meaningful deliberation in other settings.

11 Bieber (2013, p. 395 f.) identifies a blind spot in election research with respect to an ethos of campaigning. For initial steps toward such an ethos, see Nelson et al. (2002).
} 
a communication-oriented basis for a normative ethos of digital campaigning ${ }^{11}$ to which parties should commit. ${ }^{12}$

As we have endeavored to show, political parties, alongside initiating and perpetuating the free exchange of opinions and co-determining the public sphere as a deliberative setting, act as institutionalized discursive representatives of citizens, who likewise respect the aforementioned conditions of access and rules of engagement. If we regard political advertisements as a specific type of political communication (Lippert et al. 1980, p. 109f.), it follows that their campaigning, be it onor offline, must also respect normative principles of public discourse. Habermas, drawing no explicit distinction between analog and digital formats, is convinced that one of the fundamental benefits of political advertising in general consists in its generation of "competing public opinions on topics relevant for decision-making" (Habermas 2018, p. 877), which is exceedingly vital for ensuring "informed and considered decisions [...] in the voting booth" (ibid.). Political advertising therefore appears essential to deliberative politics due to its opinion-forming function; yet its design, dissemination, and evaluation require the application of a set of deliberative principles. Political advertising can make a positive contribution to the quality of deliberative democracy by providing valuable keynotes for subsequent deliberation or introducing arguments that themselves enhance the deliberative process via which public opinion and a public will emerge (Habermas 2018, p. 877), inspiring people to reflect on their views, or convincing them to alter their opinions by the force of other, possibly better arguments. In many instances, political advertisements will fall into the category of strategic persuasion (rather than deliberative persuasion, cf. Klemp 2011, p. 75). Nevertheless, we may regard them as increasing voters' (public) autonomy, that is, democratic citizens' access to self-legislation and democratic self-government (cf. Habermas 2020, p. 10; Lafont 2020, p. 17; Zurn 2019, p. 349), and consequently the quality of deliberative democracy, as political ads ideally contain crucial information for the citizenry. By contrast, advertisements that are solely offensive to others or do not convey any substantial content may have a destructive effect on deliberative politics, as they will serve to intimidate potential participants in deliberation and ultimately restrict free and uncoerced participation in discourse. Campaigning that disregards the core principles of public communication, such as the equality of the rights pertaining to all participants $\left(\mathrm{P}_{1}, \mathrm{P}_{2}, \mathrm{P}_{3}\right)$ and the acceptance of the "unforced force of the better argument" $\left(\mathrm{P}_{6}\right)$, will induce conditions under which phenomena such as "filter bubbles" and "echo chambers" thrive and systematic manipulation of deliberation and of the structural conditions for open and equal communication occur-the upshot being dangerous distortions of public opinion and, potentially, a decline, via direct or indirect means, in the discursive level of the public sphere. ${ }^{13}$

\footnotetext{
12 Civil society organizations are currently advocating politically "fair" competition among parties and the content they disseminate. For example, the German association D64 (Center for Digital Progress) argued, in the context of the German "super-election year" 2021, for a code of conduct for digital campaigning to which political parties' compliance would have been mandatory and which would have included requirements for comprehensible targeting and the reliable protection of personal data (D 64 2021). Political and social foundations, such as Stiftung Neue Verantwortung (SNV 2020), have issued similar calls.
}

13 On the discursive level of public election campaigns, see Ottmann (2015, p. 233). 
Given these circumstances, it is a reasonable assumption that some content spread via digital campaigning, such as messaging consisting purely of insults or the more subtle defamation of particular social groups, violates a range of central rules of discourse $\left(\mathrm{P}_{2}, \mathrm{P}_{5}, \mathrm{P}_{6}\right)$ and, in so doing, delegitimizes the political party issuing such messaging as a deliberative actor in the democratic process. Further, the violation of these communicative principles $\left(\mathrm{P}_{1}, \mathrm{P}_{2}, \mathrm{P}_{5}, \mathrm{P}_{6}\right)$ may alter the fundamental structures of political communication and of society per se. In advancing polarization in discourse and producing "more heat than light", specific types of digital campaigning promote the fragmentation of the political public sphere. In this regard, Habermas's concerns about the possibility of profound fragmentation of the digital mass audience and therefore the collapse of the overall audience in virtual space into a multitude of discrete groupings appear highly resonant in the assessment of digital campaigning (Habermas 2009, p. $157 \mathrm{f}$.). As soon as "digital citizens" retreat into "echo chambers" or "filter bubbles" to escape the hatred and hostility of others as occurs, for example, in defamatory and derogatory campaigning, ideal deliberation is no longer feasible. In the long term, a form of silencing occurs; digital citizens retreating from the digital public sphere may no longer dare to unconstrainedly express their opinions in discourse and can therefore no longer participate as equals in the formation of political opinion $\left(\mathrm{P}_{1}, \mathrm{P}_{2}, \mathrm{P}_{3}\right)$. This may eventually lead to the effectively permanent exclusion of entire societal groups and their views from what would ideally have been a free and open process of deliberation $\left(\mathrm{P}_{1}, \mathrm{P}_{2}, \mathrm{P}_{3}, \mathrm{P}_{5}\right)$. In this scenario, the terrain has become too hostile for arguments, opinions and ideas to hold their ground, and the discourse becomes partial in the literal sense of the term, because it is now no longer the case that all relevant arguments are being raised and heard $\left(\mathrm{P}_{1}, \mathrm{P}_{2}\right)$. Indeed, given the looming fragmentation of internet audiences, the democratic nature of elections itself appears to be at stake: "Democratic elections cease to function properly, for example, [...] when the infrastructures of public communication disintegrate to such an extent that dulling resentment, instead of well-informed public opinions, gains the upper hand" (Habermas 2018, p. 872). Normative principles that seek to avert the emergence of such "dulling resentment", the "failure to take into account the interests of underprivileged non-voters" (ibid.), and other violations of Habermas's discursive rules will therefore serve a useful purpose in the normative assessment of digital campaigning.

Both the phenomenon of microtargeting and the spread of "dark ads"14 may indeed actively perpetuate the violation of Habermasian communicative principles and their underlying structures. These practices share an element of the conscious and active withholding of particular content (i.e. information, arguments, or political statements) from some citizens, that is, those not deemed part of the relevant target group $\left(\mathrm{P}_{4}\right)$. This, in turn, violates the central principles of discursive trans-

\footnotetext{
${ }^{14}$ The term "dark ads" or "dark advertising" refers to a specific phenomenon of online advertising in which the content in question is visible only to the publisher(s) of the advertisement and the target group it seeks to address. The introduction of "ad archives", which contain all digitally published content and are accessible to anyone interested, has created a challenge to dark ads on the legal plane; this de jure deactivation, however, has not erased their de facto continued dissemination, as access to ad archives, itself relatively rarely availed of, calls for active research and comparison which many do not choose to, or are not aware they can, undertake.
} 
parency and openness, as well as bringing equality of participation, rights, and the acquisition of information-which is crucial to the formation of political opinion-into disequilibrium $\left(\mathrm{P}_{1}, \mathrm{P}_{2}, \mathrm{P}_{3}, \mathrm{P}_{5}\right)$. Both "dark ads" and microtargeting —or, more specifically, their effects as exclusionary mechanisms of silencing-violate the fundamental premises of universal access and equal treatment of all participants. If the infringement of these principles has the chilling effect of causing people to withdraw from the digital public sphere and online deliberation, be it to protect themselves from online attacks or out of apathy and cynicism, a reduction in the diversity of arguments advanced and limitations on access to political participation would be only two of the logical consequences of this development, and they would ultimately undermine deliberative democracy. As Dobber et al. (2019b, 1213) put it, a "voter may, for example, not seek out information about the standpoints of certain political parties [...] because she feels she is being watched, or [...] fears third parties can use her information [...] to infer private information". From the viewpoint of theories of democracy, it is vital, if public deliberation is to continue in a healthy and productive manner, to avoid the chilling effects unleashed by such non-transparent influencing techniques. Further, "dark ads" in particular engender a fundamental lack of transparency as to an ideal discourse, because their use means neither other political parties, the media nor other citizens know who received what specific piece of information $\left(\mathrm{P}_{5}\right)$. This withholds from the discourse the shared information base necessary to its inclusivity and places particular participants, those holding more or other information, in a more favorable position $\left(\mathrm{P}_{5}\right)$. Both microtargeting and "dark ads" can contribute to the emergence of online "echo chambers" which reinforce people's views and shelter them from confrontation with other, potentially challenging arguments or ideas. With these impacts in mind, it should be incumbent upon political parties to design their digital campaigning strategies in such a way as to effectively prevent the formation of echo chambers and filter bubbles.

Similar discursive violations are also a grave risk associated with negative campaigning. This practice predates the digital era; however, some of the possibilities opened up by the digital, such as recourse to huge amounts of pre-collected data and sophisticated techniques of constant monitoring and quantification of the public mood, on the basis of which organizations can craft and disseminate corresponding messages within seconds, expand the scope and thus the incentives for negative campaigning in the digital age. If we proceed from the assumption that negative campaigning is tantamount to subversion of the objective and argumentative structure of deliberation $\left(\mathrm{P}_{4}\right)$ due to its purposeful disadvantaging of a specific actor (such as a political party or an elected official) and that it has the capacity to limit or even completely destroy mutual respect among all disputants and force the exclusion of some participants $\left(\mathrm{P}_{1}, \mathrm{P}_{2}, \mathrm{P}_{3}, \mathrm{P}_{5}\right)$, we can perceive a severe challenge to Habermasian principles of discourse in its use.

Alongside these damaging consequences of specific aspects of digital campaigning, the practice's sociotechnical foundation poses a threat of its own. The basis of digital campaigning is the extensive collection of data, that is, of information about voters subsequently employed for the purpose of covertly influencing these voters toward particular voting behaviors. In other words, regardless of its content, digital campaigning inescapably operates with hidden information and power asymmetries 
between party and voter; this modus operandi alone therefore presents a danger to the principles of equality and mutual respect $\left(\mathrm{P}_{5}\right)$. In most instances, voters are not fully aware of these power asymmetries; on top of this, psychographic profiling uses emotional manipulation and techniques of persuasion. These circumstances mean that political microtargeting will very often amount to manipulation that diminishes its object's autonomy by working with hidden or irrational force (cf. Klemp 2011, p. 75).

In our view, the hazards highlighted in this discussion underline the need for a set of normative principles which would govern digital campaigning in such a way as to safeguard the deliberative overall quality of discursive politics. We consider that political parties need to be aware of their vital deliberative role within the political system and the normative responsibility this entails. Under the assumption that digital political advertising, notwithstanding its function as a means of strategic persuasion, enables and influences deliberations taking place in other settings, we believe that Habermas's democratic theory requires political parties to act in accordance with discursive principles as set out for deliberative debates. This implies responsibilities with respect to the content and dissemination of political advertising, alongside vital responsibilities regarding advertisements' sociotechnical design. It is our view that failure on the part of political parties to adhere to these principles risks seriously jeopardizing a transparent, open, and lively deliberative political culture in the public sphere. The segmentation, fragmentation and isolation of the electorate inherent to microtargeting and "dark ads", and the use of hidden or irrational force, hold the potential to change society in ways that massively endanger the conditions that need to be in place for effective and equitable deliberation, which in the long run will threaten both democratic opinion-forming processes and the institution of the democratic election itself.

\subsection{Applying of Rawls's principles of public reason to digital campaigning}

Rawls may appear to have little to say to us about digital campaigning. He wrote most of his political theory before the proliferation of digital technologies; he writes little about political parties in general; and where he does engage with the subject, his thoughts might seem not to extend beyond a vague skepticism toward parties or a blanket critique of the mode of public debate (Muirhead and Rosenblum 2006, p. 99). In our view, however, Rawls's political theory ${ }^{15}$ does encompass principles amenable to development into a normative theory of political parties and to the addressing of our concerns around the design and evaluation of digital campaigning. As recent research has rightly emphasized, Rawls's idea of public reason represents a principle of political legitimacy, stability, and quality whose application to political parties as special deliberative actors is plausible or indeed necessary.

\footnotetext{
15 This article places a focal emphasis on Rawls's later works $(1999,2001)$ due to the specific perspective on public reason they contain. For a discussion of how Rawls's earlier and later works delineate his theory of public reason from a variety of perspectives, see Rawls (1999, p. 614).
} 


\subsubsection{Rawls's principle of public reason and the "duty of public civility"}

In Rawls's conception of public reason, the exercise of coercive power is legitimate only if it can be justified on grounds that can be accepted by all citizens deliberating as the free and equal actors they are (Rawls 2001, p. 91). The application of public reason in this sense, however, is to take place "not in general for all the questions to be settled by the legislature" (Rawls 2001, p. 91; n. 13), but "at least when constitutional essentials and questions of basic justice are at stake" (Rawls 2001, p. $90 \mathrm{f}.){ }^{16}$

Rawls's "wide view" of public reason seems rather flexible with respect to the combination of different justifications: Comprehensive religious or philosophical doctrines can be brought to the public forum. This brings the "advantage of citizens informing one another where they come from" (Rawls 2001, p. 90). But the "duty of civility" requires that these reasons be complemented with public reasons within a certain timeframe (Rawls calls this the "proviso") — i.e. justifications based on the political values of the conception of justice with which other citizens, deliberating in their free and equal citizenness, might agree (Rawls 2001, p. 90).

It is important to note that this idea of public reason is not just a principle of political legitimacy, but also a principle of the quality and stability of democratic constitutional regimes; these properties require civic virtues that themselves depend on the structure and quality of public discourse. Underlying Rawls's lament on the current political debate is his view that civic virtues are acquired in public discourse and thus find themselves in danger where a debate fails to give expression to the civic virtues of fairness, compromise, and mutual respect. The fact that "much political debate betrays the marks of warfare [...] consists in rallying the troops and intimidating the other side" (Rawls 2001, p. 118) is a problem, particularly as it endangers democratic virtues such as the "cooperative political virtues of reasonableness and a sense of fairness, of a spirit of compromise" (ibid.). These virtues are slowly built and easily destroyed. Like " "capital' [...] these virtues can depreciate, as it were, and must be constantly renewed by being reaffirmed and acted on in the present" (Rawls 2001, p. 118). Protection of this "capital of a constitutional democracy" therefore calls us to limit ourselves in public communication to "just forms of warfare"- to act decently and to give reasons that are addressed to citizens as citizens (Rawls 2001, p. 118).

Stated as a principle of quality and stability, the "duty of public civility" seems to be more comprehensive than the principle of legitimacy, because it applies, not solely to "constitutional essentials", but "also in other cases insofar they border on those essentials and become politically divisive"-indeed, "especially when they become divisive" (Rawls 2001, p. 117). Public political culture has effects on citizens "political character" (ibid.). The duty of public civility thus implies a civic duty "to fashion a certain kind of social world" which is not "given by history, but, at least in part, [...] up to them" (Rawls 2001, p. 118) — a duty, then, which would pertain to a policy of the promotion of democracy. Rawls warns us against underestimating

16 Clear definition of the cases requiring the application of public reason appears no easy matter. For a discussion of this problem, see Bonotti (2017, p. 67) and Tinnevelt (2020, p. 114). 
the necessity of constantly cultivating civic virtues, a practice he regards as an indispensable precondition for the stability and quality of all existing constitutional democracies (Rawls 1999, p. 610).

The duty of public civility does not set harsh limits on the content of public speeches, but rather demands the employment of a certain civic mode which obeys the principle of reciprocity and expresses mutual respect. First, public reasoning is a dialogue-oriented mode that proceeds from the fact of pluralism, takes seriously the need for a participant in discourse to justify her own position, and expresses respect for those who may hold a different view. "Public justification" is therefore "not simply valid reasoning, but argument addressed to others" (Rawls 1999, p. 594). Judges, legislators, and other government officials fulfill their duty of public civility if they "explain to other citizens their reasons for supporting fundamental political positions in terms of the political conception of justice they regard as the most reasonable" (Rawls 1999, p. 576). They address these reasons to other citizens as citizens, that is, to citizens who regard themselves as free and equal, and neither to individuals who espouse comprehensive doctrines nor to socially situated individuals who hold particular group-based interests (Rawls 1999, p. $607 \mathrm{f}$.). The task of the criterion of reciprocity, which the public use of reason expresses, is to specify "the nature of the political relation in a constitutional democratic regime as one of civic friendship" (Rawls 1999, p. 579).

On the strength of these considerations, we may summarize Rawls's idea of "public reason" as a principle of legitimacy and a principle that contributes to the quality and stability of constitutional democracies. The duty of public civility is a moral, not a legal duty: ${ }^{17}$ When speaking publicly, citizens should provide reasons for their views, with which other people might agree as free and equal citizens. They should choose language that expresses respect for other citizens as free and equal, and in so doing contribute to expressing political relations in constitutional democracy as relations of civic friendship.

\subsubsection{Political parties in Rawls's idea of deliberative democracy and parties' duty of civility}

Rawls's moral duty of civility applies only in the public forum, and not in the background culture (Rawls 1999, p. 576). But in the public forum, it applies in principle to all participants. Although the moral duty "applies more strictly to judges than to others, [...] the requirements of public justification [...] are always the same." Ideally, ordinary citizens "are to think of themselves as if they were legislators" (Rawls 1999 , p. 575 f.). Therefore, the moral duty of public civility should also be incumbent on political parties in the public forum who engage in public campaigning. Rawls's enumeration of actors subject to the duty of civility is not limited to judges and government officials. In his last full discussion of the idea of public reason, he also explicitly refers to political parties and managers of election campaigns. Within the "public political forum", the idea of public reason extends "to the discourse of

${ }^{17}$ Cf. Rawls (1999, p. 577): "I emphasize that it is not a legal duty, for in that case it would be incompatible with free speech." 
candidates for public office and their campaign managers, especially in their public oratory, party platforms, and political statements" (Rawls 1999, p. 575). ${ }^{18}$

What we have yet to fully understand from these discussions is why Rawls places the duty of civility upon campaigning political parties. Is the party's duty the same duty as that pertaining to each citizen? We will argue that it is not. Instead, we read Rawls as providing components of a normative theory of political parties as unique deliberative actors (as Muirhead/Rosenblum (2006) and Bonotti (2017) convincingly argued ${ }^{19}$ ). And it is political parties' unique role in deliberation from which arises their special responsibility as public deliberators in campaigning. One of the reasons for this special position is the great public interest political parties' election campaigns usually attract, which gives them a more substantial capacity to influence public deliberation than other actors may have. If public communication always holds the status of an enabling environment for the formation of civic virtues, then it follows that actors with substantive influence on public communication also have a special political responsibility to bear; if the general duty of civility implies a duty to contribute to the formation of the public political culture, this is still more the case for actors whose role in this public forum confers on them a specific ability "to fashion the social world". Implicit in Rawls's call for public funding of political parties' campaigning is a view of campaigning parties as central actors in the public use of reason, to which they can only make an appropriate contribution, free from the "distort[ing]" influence of "corporate and other organized interests", if they are liberated, as far as possible, from the "curse of money" (Rawls 1999, p. 580).

A second factor determining campaigning political parties' deliberative responsibility is their contribution to the "overlapping consensus" that, in Rawls's view, guarantees stability in diverse societies (see Bonotti 2017, p. $3 \mathrm{f}$.): By acting as "loudspeakers", setting and structuring the political agenda, and advancing political programs, they add legitimacy to, and shore up a stable common ground for public deliberation in a democratic constitutional regime. This role-modeling, legitimizing, and stabilizing function of political parties stems from their unique role which, as argued by Rosenblum and Muirhead (2006, p. 104), consists in their mediating between society and the state, between background culture and public culture. As mediating institutions, political parties are required to master the art of "bilingual" communication (ibid.): In their representative and articulative function, they need to take sufficient account of the particular interests and viewpoints of their members (and of their voters' non-public reasons; Bonotti 2017, p. 5). However, in election campaigns, parties, or, more specifically, party members, also act as candidates for public office and thus represent potential legislators. Parties therefore-at least potentially-represent the state insofar as they represent candidates for holders of "public offices," who in their public advancement of reasoning must address all citizens as citizens and give public reason. In election campaigns and in their attempts to bring their candidates into public office, party members carry around, as Bonotti

\footnotetext{
18 Rawls asserts that candidates for election are responsible for what is said and done by party officials and campaign managers on their behalf (Rawls 1999, p. 575).

19 For a critical discussion of recent literature on the normative theory of political parties, see Muirhead/ Rosenblum (2020).
} 
(2017, p. 67) puts it, a "portable public realm," and are thus subject to the duty of civility. As well, then, as representing the fact of pluralism from which Rawls's political liberalism takes its starting point, political parties that present their election candidates to the public as future holders of public office have the civic duty to represent the use of public reason as an appropriate mode of moderating such pluralism.

This role and responsibility makes it vital for political parties to refrain from simply addressing voters as a biddable mass of potential votes or as apathetic citizens in need of politicization and mobilization. In campaigning and as (potential) representatives of the state and the public good, political parties and their members also model public reasoning and possess transformative power for the formation of civic identity and of a society's political culture. Particularly in view of the fragile, endangered state of civic virtues as "political capital", we are called to judge public speech and action by parties and candidates in election campaigns consistently (albeit not necessarily exclusively), in terms of their impact on this political capital.

\subsubsection{Political parties' "duty of public civility” in digital campaigning}

Having contended that campaigning political parties have a special duty of civility, we proceed now to consider the conclusions we may draw from that contention when it comes to designing and evaluating digital election campaigns. A brief précis of Rawls's duty of civility, which it may be worth keeping in mind here, might encompass the imperatives to present public reasons for a line of argument, to address voters as free and equal citizens, and to respect the principle of reciprocity that represents political relations as relations of civic friendship.

We might initially assume that techniques of digital political microtargeting violate the "duty of civility" due to the lack of justification behind typical political advertising, which, after all, fails to comprehensively address citizens' argumentative and deliberative abilities, instead limiting itself to "bombarding" them with claims or with announcements of future action. However, the lack of justifications alone does not necessarily constitute such a violation. Rawls's normative theory of political parties is realistic in that Rawls concedes that parties and political representatives will not be able to persuade an apathetic and cynical people (see Rawls 1999, p. 580). The obligation the "duty of civility" places on discursive actors to address citizens as citizens, rather than seeking to appeal to particular interests of groups or individuals, notwithstanding, Rawls admits that "at some point we must take these interests into account" (Rawls 1999, p. 607). If we consider that it follows from this that political parties need to, and correspondingly act to, mobilize and politicize citizens, inducing them to engage in elections and in public deliberation, we can infer a legitimate place for political advertisements that do not present instances of public reason. After all, political advertising could, in principle, contribute to the representation of plurality and to the structuring of debate, and thus prepare the 
ground for and initiate deliberation and encourage people to reflect on their views of the good. ${ }^{20}$

Having conceded, in principle, such a possible deliberative function for advertising that seeks to politically mobilize, we still need to delineate the conditions within which such a deliberative function would have to play out. If "bombardment" with bespoke party-political advertisements is visited only upon that party's potential voters on the basis of presumed preferences, there is no pluralization of viewpoints nor structuring of the debate; instead, the advertising narrows down the marketplace of ideas and treats citizens unequally with respect to their right to political information (see Bay 2018, p. 1726); the terms "filter bubbles" and "echo chambers" have become established as descriptions of this problem and its effects. From the perspective of the individual voter, "dark ads" that are visible only to particular users and/or selectively distributed advertisements violate the principle of equal access to political information. ${ }^{21}$ If people presumed to support opposing parties are "bombarded" with negative information about candidates in an election to the end of dissuading them from carrying out their supposed voting intentions, the risk is that attitudes deleterious to deliberation, such as apathy and cynicism, will come to prevail. Moreover, the digital infrastructure makes it easy for negative campaigning practices to go in the direction of smear campaigns, thus failing to uphold mutual respect among citizens as free and equal; the danger here is one of damage to the "political capital of democracy", that is, the civic virtues of fairness and mutual respect among free and equal citizens. We might conclude from this that advertising that is low on reasoning could contribute to deliberation if it avoids the practices of negative campaigning and "dark ads" as far as possible and concentrates instead on informing, mobilizing and politicizing voters (ideally addressing them as equals). The availability of simple opportunities for all citizens to access and compare various political advertisements and the positions they represent, and to access and compare different justifications for those positions (both within and between parties), therefore appear particularly conducive to generating effects that promote deliberation and the formation of a civic identity. We recommend that political parties provide equal access to political information and public reasoning and meet their duty of civility by a) creating their own, party-specific ad archives and b) supplementing low-reason advertisements directly with public reasons for the political positions they espouse and with links/materials providing information on their full manifesto.

It is additionally vital to reflect here on the sociotechnical foundations of digital campaigning. Unlike advertisements in election campaigns of the pre-digital

\footnotetext{
20 It might also be conceivable to formulate a proviso for political advertisements that lack reasons similar to that which governs the introduction of comprehensive doctrines (that offer the wrong reasons) to the political forum: Both, that is, the absence of justifications and the introduction of problematic justifications, could serve important purposes in the context of the public use of reason and be permitted, provided that the relevant actor supplements them with public justifications addressed to free and equal citizens within a reasonable timeframe after issuing the advertisement.

21 Platform ad archives cannot provide a full solution to this problem, because they require the user to engage in a number of different actions, accessing and comparing the advertisements, if she is to attain an equal level of information.
} 
era-for all these often similarly lacked detailed justifications for their positionspractices of digital campaigning are based on comprehensive collections of data that create an asymmetry of information between parties and citizens and harness this asymmetry, together with insights from behavioral psychology, to intervene in the processes by which individual citizens attain and develop their idea of the good and their political will. The sociotechnical basis (extensive collection of data) and objectives (behavioral change through appeals to individual preferences or pre-existing biases) of digital microtargeting thus show little overall respect for the value of privacy, for symmetrical relationships in communication, and for the civic capacity and right of free formation of political will pertaining to every citizen. Given the use of hidden and irrational force which they may involve, we can regard the sociotechnical foundations of political microtargeting as a form of manipulation that diminishes its targets' autonomy. The much-vaunted potential antidote to this drawback of microtargeting (Susser et al. 2019, p. 14), boosting transparency and increasing voters' awareness about the data collected on them and their use, may not in fact solve the problem, as it may transmit and express a certain image of the citizen as bundle of preferences ${ }^{22}$ that endangers the self-respect which Rawls regards citizens as urgently requiring for their autonomy: "Without it nothing may seem worth doing, or if some things have value for us, we lack the will to strive for them. All desire and activity becomes empty and vain, and we sink into apathy and cynicism" (Rawls 1971, p. 440). If a citizen is to attain a perception of herself as someone who, like all other citizens, is able and entitled to form her own ideas of the good and to change them in the course of her life, she will need to have grown up within legal and social structures that do not hinder the development of this civic self-esteem. Rawls emphasizes the need for a public political culture that supports and encourages such self-respect: "If citizens of a well-ordered society are to recognize one another as free and equal, basic institutions must educate them to this conception of themselves, as well as publicly exhibit and encourage this ideal of political justice. [...] Acquaintance with and participation in that public culture is one way citizens learn to conceive of themselves as free and equal [...]." (Rawls 2001, p. 56) In our view, it is possible to reformulate Rawls's thesis of the social foundations of civic self-respect as a thesis of the sociotechnical foundations of civic self-respect (cf. Hoffmann 2020) and apply it, thus recontextualized, to the field of digital campaigning:

Because the practice of digital political microtargeting is based on massive asymmetries of information (see Tufekci 2014) and power (cf. Bay 2018, p. 1727) between party and voter, and among individual voters, it can impact a citizen's self-perception as someone with equal opportunities and rights to freely form her own political judgments. This is especially likely to occur when advertisements are highly personalized and based on intricate psychological personality profiles, as in "psychographic profiling" (see Burkell/Regan 2019, p. 2). Further, because the practice of digital political microtargeting amounts to the construction of a personalized choice envi-

\footnotetext{
22 Baldwin-Philippi (2015, p. 12f.) claims that digital campaigning might change normative images of citizenship, but she does not consider this regrettable, nor does she discuss the extent to which these altered normative images might affect or even endanger citizens' self-respect (understood in a Rawlsian manner).
} 
ronment and thus represents an intervention in an individual's personal sphere of political will formation with the aim of manipulating behavior, it may act to jeopardize a person's self-perception as a free, autonomous citizen capable of developing his or her own ideas of the good. ${ }^{23}$ Even if, contrary to some of the warnings we hear about their extreme manipulability, citizens are not simply puppets without wills of their own, ${ }^{24}$ they depend, for the formation and exercise of their civic capacities, on a conception of themselves as free and equal and as entitled to, and possessing the capacity to, generate their own ideas of the good and revise them as they see fit. Sociotechnical structures and practices that are transparent with respect to the data and techniques of psychographic profiling they have used, and in so doing make inferable a view of the citizen as a bundle of preferences and biases susceptible to manipulation by asymmetries of power and information, are certainly not conducive to the formation of such a self-perception as a free and equal citizen. ${ }^{25}$ An increase of transparency, which was discussed as a solution for the segmentation problem and as a way for a party to meet its "duty of civility", thus seems to raise new problems.

If political parties' duty of civility, then, implies their responsibility for the political capital of civic virtues and the formation of citizens' political character, it is incumbent on them to have regard to the potential for some microtargeting techniques to harm the formation of "civic self-respect". While further empirical studies around these expected effects would add precision to the picture, it would seem wise until then for political parties to a) at least refrain from engaging in psychographic profiling, b) provide all citizens with equal access to all their advertisements (partyspecific ad archives), and c) supplement advertisements with links to material providing justifications and giving public reasons-which would support the formation of a civic identity founded on citizens' self-conception as free and equal, possessing the right and ability to develop their own ideas of the good. We believe, in short, that political parties should progress beyond a view of digital campaigning as simply a tool for "winning votes", instead regarding it as a policy of democracy promotion, that is, as a way to support the development of the civic virtues and civic identity that the quality and stability of constitutional democratic regimes urgently require.

\section{Discussion and conclusion}

This article has shown how Rawls's and Habermas's theories of democracy can each provide insights for the evaluation and design of digital political microtargeting. Through the lens of an emerging normative theory of the political party as a deliberative actor, we have argued that parties have special responsibilities when they engage in digital campaigning. We believe they should, at least to a certain degree, regard their campaigns, alongside their function of gaining votes, as means

\footnotetext{
23 A similar argument regarding nudging is in Nys/Engelen (2017).

24 On recent discussions of the danger of manipulating citizens through microtargeting, cf. Burkell/Regan (2019), Susser et al. (2019), Gorton (2016).

25 Recent studies explore privacy concerns and acts of silencing and self-censorship arising from increased awareness of online surveillance to manipulative ends; see Dobber et al. 2019b and Harker (2020).
} 
of enabling public deliberation in other settings, of "fashion[ing] the social world" (Rawls), of contributing to the formation of a civic identity-and thus as instances and manifestations of a policy of democracy promotion. Practical implications of this approach would include an increased level of transparency, the creation of partyspecific ad archives, the linking of ads with more comprehensive materials and more complex justifications (and public reason-giving), and the abandonment of psychographic profiling, "dark ads", and negative campaigning, all practices which potentially cause harm to the formation of a civic identity in the Rawlsian sense.

Critics may object at this point that a) self-regulation of parties is neither realistic nor sufficient and we instead need laws regulating online platforms and political parties, ${ }^{26}$ and that b) we should not treat parties as philosophical, but primarily as politicizing and mobilizing entities (Muirhead 2019, p. $85 \mathrm{f}$.). To the first point, we would answer: yes, more regulation may be needed. But one problem in this respect is that governing political parties themselves will be charged with creating these regulatory instruments and in so doing effectively depriving themselves of some of their most powerful vote-winning techniques (see Harker 2020, p. 156). It appears more apposite, albeit less instantly effective, to reflect societally on vital components of political parties' normative role in deliberative democracies. To Rawls (1999, p. 577), the ordinary citizen's "duty of civility" is to carefully select individuals for public office who value public reason, and to repudiate candidates and parties who fail to honor it. Citizens who accept this duty (1999, p. 605) and parties who accept their "duty of civility" can thus work together, independently and reciprocally supporting one another's endeavors, to strengthen deliberative democracy. Increased public understanding of aspects of certain campaigning practices that are problematic from a normative perspective of deliberative democracy may cause some of these practices to lose their strategic appeal to political parties for fear that voters might act on their awareness and express their rejection of them in their voting decisions.

In response to the second point-that political parties are not philosophical entities-we would observe that the most important element of theory-building in this context is not to "choose" between two (or more) roles of parties, but to give a thorough, nuanced account of these roles in their various intertwinements and contexts. There may be instances in which campaigning political parties have to choose between providing justification for their statements and voter mobilization (Muirhead 2019 , p. 87). This, however, does not imply that our normative theories of political parties should favor mobilization over justification in general (Muirhead 2019, p. 87). In public campaigning, parties present candidates for public office and legislative proposals that require justification to all citizens; should this not take place, the "language of the street" may degenerate into a simplistic, non-evidenced argumentum ad populum such as "A lot of people are saying"-a mode of politics that Muirhead and Rosenblum (2019) rightly criticize. Mobilizing voters and reestablishing genuine connections between citizens and the state are crucial functions of political parties in deliberative democracies - but campaigning parties that select and present candidates for public office should not forget their "duty of civility." We note a need

26 See Dobber et al. 2019a. For a discussion of multi-stakeholder or co-regulatory mechanisms, see Burkell/Regan (2019). 
for research to add further nuance and sharpness to deliberative theories of democracy to enable them to engage in analysis of the various remits and roles of political parties, including as they pertain to different points in time (such as before and after elections) and spheres of societal life (parliament, background culture, the public forum, intra-party communication). The rich literature in the field of comparative political science around the roles and functions of political parties is likely to be of great help in producing a more realistic and context-sensitive account of political parties within theories of deliberative democracy and the normative demands we, as societies, can make of them in the context of election campaigns. The analysis of digital political microtargeting presented here thus shows that the application of normative theories of democracy to the digital context is a route to learning about the design and evaluation of digital practices and a spotlight on remaining lacunae and areas of political theory currently underdeveloped in respect to digital settings and configurations (see Berg et al. 2020).

Funding Open Access funding enabled and organized by Projekt DEAL.

Open Access This article is licensed under a Creative Commons Attribution 4.0 International License, which permits use, sharing, adaptation, distribution and reproduction in any medium or format, as long as you give appropriate credit to the original author(s) and the source, provide a link to the Creative Commons licence, and indicate if changes were made. The images or other third party material in this article are included in the article's Creative Commons licence, unless indicated otherwise in a credit line to the material. If material is not included in the article's Creative Commons licence and your intended use is not permitted by statutory regulation or exceeds the permitted use, you will need to obtain permission directly from the copyright holder. To view a copy of this licence, visit http://creativecommons.org/licenses/by/4. $0 \%$.

\section{References}

Achen, Christopher H., and Larry M. Bartels. 2016. Democracy for realists. Why elections do not produce responsive government. Princeton: Princeton University Press.

Baldwin-Philippi, Jessica. 2015. Using technology, building democracy. Digital campaigning and the construction of citizenship. Oxford: Oxford University Press.

Baldwin-Philippi, Jessica, Letitia Bode, Daniel Kreiss, and Adam Sheingate. 2020. Digital political ethics: aligning principles with practice. https://citapdigitalpolitics.com/?page_id=1911. Accessed 2021-0213.

Bay, Morten. 2018. The ethics of psychometrics in social media: a Rawlsian approach. ACM Transactions on Social Computing https://doi.org/10.1145/3281450.

Becker, Hartmuth. 2003. Die Parlamentarismuskritik bei Carl Schmitt und Jürgen Habermas. Berlin: Duncker \& Humblot.

Bennett, Colin J. 2016. Voter databases, micro-targeting, and data protection law: can political parties campaign in Europe as they do in North America? International Data Privacy Law 6(4):261-275.

Berg, Sebastian, Niklas Rakowski, and Thorsten Thiel. 2020. Die digitale Konstellation. Eine Positionsbestimmung. Zeitschrift für Politikwissenschaft 30:71-191. https://doi.org/10.1007/s41358-020-002076.

Bieber, Christoph. 2013. Wahlen, Wahlkampf und Ethik. Anmerkungen zu einem toten Winkel der Wahlforschung. Communicatio Socialis 46:394-403.

Blake, Nigel. 1995. Ideal speech conditions, modern discourse and education. Journal of Philosophy of Education 29(3):355-367.

Bohman, James. 1996. Public deliberation. Pluralism, complexity, and democracy. Cambridge, London: MIT Press.

Bonotti, Matteo. 2017. Partisanship and political liberalism in diverse societies. Oxford: Oxford University Press. 
Brunkhorst, Hauke, Regina Kreide, and Cristina Lafont (eds.). 2009. Habermas-Handbuch. Wiesbaden: Springer.

Burkell, Jacquelyn, and Priscilla M. Regan. 2019. Voter preferences, voter manipulation, voter analytics: policy options for less surveillance and more autonomy. Internet Policy Review https://doi.org/10. $14763 / 2019.4 .1438$.

D 64. 2021. Code of conduct for digital campaigning. https://d-64.org/wp-content/uploads/2021/06/D64_ Code_of_Conduct_Eng.pdf. Accessed 10 Sept 2021.

Dobber, Tom, Ronan Ó. Fataigh, and Frederik Zuiderveen Borgesius. 2019a. The regulation of online political microtargeting in Europe. Internet Policy Review 8(4). https://doi.org/10.14763/2019.4.1440.

Dobber, Tom, Damian Trilling, Natali Helberger, and Claes de Vreese. 2019b. Spiraling downward: The reciprocal relation between attitude toward political behavioral targeting and privacy concerns. new media and society 21:1212-1231. https://doi.org/10.1177/1461444818813372.

Downs, Anthony. 1957. An economic theory of democracy. New York: Harper \& Brothers.

Gardner, James E. 2009. What are campaigns for? The role of persuasion in electoral law and politics. Oxford: Oxford University Press.

Gaus, Daniel. 2013. Qualität statt Partizipation und Gleichheit? Eine Bemerkung zum epistemischen Sinn von Demokratie. Leviathan 41(2):264-290.

Gorton, William A. 2016. Manipulating citizens: how political campaigns' use of behavioral science harms democracy. New Political Science 38:61-80. https://doi.org/10.1080/07393148.2015.1125119.

Görtz, David. 2015. Das Umsetzungpotential deliberativer Demokratiekonzepte im Internet. DuisburgEssen: Universität Duisburg-Essen. Dissertationsschrift.

Greve, Jens. 2009. Jürgen Habermas. Eine Einführung. Konstanz: UVK.

Habermas, Jürgen. 1984. Vorlesungen zu einer sprachtheoretischen Grundlegung der Soziologie (1970/71). In Vorstudien und Ergänzungen zur Theorie des kommunikativen Handelns, ed. Jürgen Habermas, 11-126. Frankfurt a.M.: Suhrkamp.

Habermas, Jürgen. 1991. Erläuterungen zur Diskursethik. Frankfurt a.M.: Suhrkamp.

Habermas, Jürgen. 1996. Between facts and norms: contributions to a discourse theory of law and democracy. Cambridge: MIT Press.

Habermas, Jürgen. 2004. Wahrheit und Rechtfertigung: Philosophische Aufsätze. Frankfurt a.M.: Suhrkamp.

Habermas, Jürgen. 2006. Political communication in media society: Does democracy still enjoy an epistemic dimension? The impact of normative theory on empirical research. Communication theory 16(4):411-426.

Habermas, Jürgen. 2009. Europe. The faltering project. Hoboken: Wiley. Translated by Ciaran Cronin.

Habermas, Jürgen. 2012. The crisis of the European Union: a response. Cambridge: Polity Press.

Habermas, Jürgen. 2018. Interview with Jürgen Habermas. September 2016. In The oxford handbook of deliberative democracy, ed. André Bächtiger, John S. Dryzek, Jane Mansbridge, and Mark E. Warren, 871-882. Oxford: Oxford University Press. Translated by Ciaran Cronin.

Habermas, Jürgen. 2020. Commentary on, Cristina Lafont. Democracy without shortcuts. Journal of Deliberative Democracy 16(2):10-14. https://doi.org/10.16997/jdd.397.

Harker, Michael. 2020. Political advertising revisited: digital campaigning and protecting democratic discourse. Legal Studies 40:151-171. https://doi.org/10.1017/lst.2019.24.

Hoffmann, Anna Lauren. 2020. Rawls, information technology, and the sociotechnical bases of self-respect. In The oxford handbook of philosophy of technology, ed. Shannon Vallor. Oxford: Oxford University Press. https://doi.org/10.1093/oxfordhb/9780190851187.013.15.

Hudget, Holger. 2007. Demokratisierung der EU: normative Demokratietheorie und Governance-Praxis im europäischen Mehrebenensystem. Wiesbaden: Springer.

Johnson, James. 2006. Political parties and deliberative democracy? In Handbook of party politics, ed. Richard S. Katz, William Crotty, 47-50. Los Angeles: SAGE.

Jun, Uwe. 2013. Typen und Funktionen von Parteien. In Handbuch Parteienforschung, ed. Oskar Niedermayer, 119-144. Wiesbaden: Springer VS.

Klemp, Nathaniel. 2011. When rhetoric turns manipulative: disentangling persuasion and manipulation. In Manipulating democracy. Democratic theory, political psychology, and mass media, ed. Wayne Le Cheminant, John M. Parrish, 59-86. New York, London: Routledge.

Kofi Annan Commission on Elections and Democracy in the Digital Age. 2020. Protecting electoral integrity in the digital age: the report of the Kofi Annan commission on elections and democracy in the digital age. https://www.kofiannanfoundation.org/app/uploads/2020/01/f035dd8e-kaf_kacedda_ report_2019_web.pdf. Accessed 10 Sept 2021.

Kruschinski, Simon, and André Haller. 2017. Restrictions on data-driven political micro-targeting in Germany. Internet Policy Review 6(4):1-23. https://doi.org/10.14763/2017.4.780. 
Lafont, Cristina. 2020. Democracy without shortcuts. A participatory conception of deliberative democracy. Oxford: Oxford University Press.

Landwehr, Claudia. 2012. Demokratische Legitimation durch rationale Kommunikation. Theorien deliberativer Demokratie. In Normative Demokratietheorien Zeitgenössische Demokratietheorie, Vol. 1, ed. Oliver Lembcke, Claudia Ritzi, and Gary S. Schaal, 355-386. Wiesbaden: Springer VS.

Lechner, Julian. 2019. Politische Theorie Politischer Parteien: Normative Elemente und innerparteiliche Konsequenzen einer Republikanischen Perspektivierung Politischer Parteien. Zeitschrift für Parteienwissenschaften 1:83-93.

Linden, Markus. 2014. Die politische Repräsentation schwacher Interessen bei Jürgen Habermas. In Deliberative Demokratie in der Diskussion, ed. Claudia Landwehr/Rainer Schmalz-Bruns, 339-368. Baden-Baden: Nomos.

Lippert, Ekkehard, Georg Räder, and Hans-Jürgen Weiß. 1980. Wahlkämpfe als spezifische Form politischer Kommunikation. In Politikfeld-Analysen 1979, ed. Thomas Ellwein, 109-122. Wiesbaden: Springer VS.

Lipsitz, Keena. 2004. Democratic theory and political campaigns. The Journal of Political Philosophy 12:163-189.

Manin, Bernard. 1987. On legitimacy and political deliberation. Political Theory 15(3):338-368.

Muirhead, Russell. 2019. Partisan justification. Political Theory 47:82-89.

Muirhead, Russell, and Nancy L. Rosenblum. 2006. Political liberalism vs. "the great game of politics": the politics of political liberalism. Perspectives on Politics 4:99-108. https://doi.org/10.1017/ S1537592706060105.

Muirhead, Russell, and Nancy L. Rosenblum. 2019. A lot of people are saying: the new conspiracism and the assalut on democracy. Princeton: Princeton University Press.

Muirhead, Russell, and Nancy L. Rosenblum. 2020. The political theory of parties and partisanship: catching up. Annual Review of Political Science 23:95-110. https://doi.org/10.1146/annurev-polisci041916-020727.

Nelson, Candice J., David A. Dulio, and Stephen K. Medvic (eds.). 2002. Shades of gray. Perspectives on campaign ethics. Washington: Brookings Institution Press.

Nys, Thomas R.V., and Bart Engelen. 2017. Judging nudging: answering the manipulation objection. Political Studies 65:199-214. https://doi.org/10.1177/0032321716629487.

Odzuck, Eva. 2020. Personalisierter Wahl-Kampf oder öffentliche Willens-Bildung? Zeitschrift für Politik 67:153-184. https://doi.org/10.5771/0044-3360-2020-2-153.

Ottmann, Henning. 2015. Was man von der deliberativen Demokratie erwarten darf. In Deliberative Demokratie, ed. Henning Ottmann, Pavo Barisic, 221-235. Baden-Baden: Nomos.

Papakyriakopoulos, Orestis, Simon Hegelich, Morteza Shahrezaye, and Juan Carlos Medina Serrano. 2018. Social media and microtargeting: political data processing and the consequences for Germany. Big Data \& Society 5:1-15. https://doi.org/10.1177/2053951718811844.

Pettit, Philip. 2004. Depoliticizing democracy. Ratio Juris 17(1):52-65.

Rasmussen, David. 2019. Ideal speech situation. In The cambridge Habermas lexicon, ed. Amy Allen, Eduardo Mendieta, 182-184. Cambridge: Cambridge University Press.

Rawls, John. 1971. A theory of justice. Cambridge: Belknap Press.

Rawls, John. 1999. Collected papers. Cambridge, London: Harvard University Press. Edited by Samuel Freeman.

Rawls, John. 2001. Justice as fairness. A restatement. Cambridge: Belknap Press. Edited by Erin Kelly.

Sartori, Giovanni. 1976. Parties and party systems: a framework for analysis. Cambridge: Cambridge University Press.

Schaal, Gary S., and Felix Heidenreich. 2009. Jürgen Habermas und die Frage nach der Rationalität des Staates. In Das Staatsverständnis von Jürgen Habermas, ed. Gary S. Schaal, 17-42. Baden-Baden: Nomos.

Schattschneider, Elmer Eric. 1942. Party government. New York: Farrar \& Rhinehart.

Schlosberg, David, and John S. Dryzek. 2002. Digital democracy: authentic or virtual? Organization \& Environment 15(3):332-335.

Schmidt, Manfred.G. 2010. Demokratietheorien. Eine Einführung. Wiesbaden: Springer VS.

Siri, Jasmin. 2011. Kritik der Gewohnheit. Der Krisendiskurs der Parteien und seine Funktion für die moderne Demokratie. Mitteilungen des Instituts für Parteienrecht 17:80-92.

Stiftung Neue Verantwortung. 2020. Rules for fair digital campaigning. https:/www.stiftung-nv.de/en/ publication/rules-fair-digital-campaigning. Accessed 10 Sept 2021.

Susser, Daniel, Beate Roessler, and Helen Nissenbaum. 2019. Technology, autonomy, and manipulation. Internet Policy Review 8:1-22. https://doi.org/10.14763/2019.2.1410. 
Tinnevelt, Ronald. 2020. Political parties and "the long road of participatory deliberative democracy". Krisis. Journal for Contemporary Philosophy 40:107-118. https://doi.org/10.21827/krisis.40.1.37060.

Tufekci, Zeynep. 2014. Engineering the public: big data, surveillance and computational politics. First Monday 19 (7). https://doi.org/10.5210/fm.v19i7.4901.

White, Jonathan, and Lea Ypi. 2019. Response: the democratic case for partisanship. Political Theory 47:106-113.

Zuiderveen Borgesius, Frederik J., Judith Möller, Sanne Kruikemeier, Ronan Ó. Fathaigh, Kristina Irion, Tom Dobber, Bodo Balasz, and Claes de Vreese. 2018. Online political microtargeting: promises and threats for democracy. Utrecht Law Review 14:82-96.

Zurn, Christopher. 2019. Private and public autonomy. In The cambridge Habermas lexicon, ed. Amy Allen, Eduardo Mendieta, 348-351. Cambridge: Cambridge University Press. 